\title{
Morphogenesis of native grasses of Pampa Biome under nitrogen fertilization
}

\author{
Juliana Medianeira Machado', Marta Gomes da Rocha1', Fernando Luiz Ferreira de Quadros ${ }^{1}$, \\ Anna Carolina Cerato Confortin ${ }^{1}$, Aline Bosak dos Santos ${ }^{1}$, Maria José de Oliveira Sichonany ${ }^{1}$, \\ Laila Arruda Ribeiro ${ }^{1}$, Aline Tatiane Nunes da Rosa ${ }^{1}$
}

${ }^{1}$ Universidade Federal de Santa Maria.

\begin{abstract}
Morphogenetic and structural characteristics of the native grasses of the Pampa Biome Andropogon lateralis, Aristida laevis, Axonopus affinis, Erianthus angustifolius, Paspalum notatum, Paspalum plicatulum, Piptochaetium montevidense and Sorghastrum pellitum were evaluated as to the effect of nitrogen (N) fertilization (zero and $100 \mathrm{~kg} N / \mathrm{ha}$ ). The experimental design was of randomized blocks with three replicates in a $8 \times 2$ (native grasses $\times \mathrm{N}$ ) factorial arrangement. Accumulated thermal sums of 350 and 700 degree days determined the interval between cuts for prostrate and caespitose growth habit species, respectively. Species considered of resource conservation (A. laevis, E. angustifolius, P. plicatulum and $S$. pellitum) had the highest leaf elongation rate when they received N. For leaf appearance rate, phyllochron, leaf senescence rate, leaf lifespan, number of green leaves and final length of leaf blades, there was difference between the evaluated species.
\end{abstract}

Key Words: leaf elongation rate, leaf lifespan, number of green leaves, phyllochron

\section{Introduction}

The Pampa biome extends from the southern half of the Rio Grande do Sul state in Brazil to Argentina and Uruguay. It is a very complex ecosystem in terms of soil and climate variations, promoting the existence of approximately 3,000 plant species, 100 mammals and almost 500 birds (MMA, 2007). Moreover, it provides forage for herds of approximately nine million cattle and about three million sheep (Anualpec, 2007). In Rio Grande do Sul state, there are approximately 400 species of grasses and 150 species of legumes belonging to botanical families of great importance from the forage point of view (Boldrini, 1997). The efficient management of these pastures requires understanding of plant responses to management practices such as $\mathrm{N}$ fertilization or defoliation frequency.

It has already been proposed (Quadros et al., 2009; Cruz et al., 2010) that grasses be clustered in functional groups as an alternative to turn more simple understanding of changes in biodiversity and management practices. Those practices could help in better utilization of grasses as forage, as well impacts in these areas, due to the importance of that botanical family in that biome.

Morphogenesis studies on native grasses of the Pampa biome have already been conducted (Cruz \& Boldrini, 1998; Trindade \& Rocha, 2001, 2002; Eggers et al., 2004) and in some of them, the effect of $\mathrm{N}$ fertilization on the morphogenetic traits of some species was evaluated (Denardin, 2001; Bandinelli et al., 2003; Nabinger et al., 2003; Santos, 2004; Quadros \& Bandinelli, 2005; Townsend, 2008). In these reports, it was verified that leaf elongation rate is positively related with $\mathrm{N}$.

In the last years, an increase in the studies emphasizing relationships between several components of grassland ecosystem was observed. In order to enhance this understanding, it is necessary to know the dynamics of generation and expansion of plant parts in space, through the study of morphogenesis of individual tillers (Lemaire \& Chapman, 1996). Those authors proposed that knowledge of morphogenetic responses to management practices as fertilization, frequency and intensity of defoliation could be the bases of developments of general practices to enhance herbage harvest efficiency.

The objective of this study was to evaluate the morphogenetic and structural characteristics of eight native grasses from the Pampa biome under two $\mathrm{N}$ fertilization levels.

\section{Material and Methods}

The experiment was carried out at Departamento de Zootecnia of Universidade Federal de Santa Maria (UFSM) from May 2008 to March 2009. The soil is classified as Paleudalf (Embrapa, 2006). Samples of soil 
collected from a $0-10 \mathrm{~cm}$ layer showed the following chemical characteristics: $\mathrm{pH}-\mathrm{H}_{2} \mathrm{O}=5.05$; $\mathrm{pH}-\mathrm{SMP}=5.12$; $\mathrm{P}=8.6 \mathrm{mg} \mathrm{dm}^{-3} ; \mathrm{K}=192 \mathrm{mg} \mathrm{dm}{ }^{-3} ; \mathrm{Al}^{3+}=0.9 \mathrm{cmol}_{\mathrm{c}} \mathrm{dm}^{-3}$;

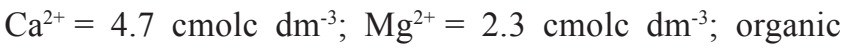
matter $=2.1 \mathrm{~g} \mathrm{~kg}^{-1}$. According to the Köppen system, climate in the region is humid subtropical (Cfa). Weather data for the experimental period was obtained from the UFSM meteorological station (Table 1).

The experimental design was a completely randomized block with three replicates. The treatments were disposed in an $8 \times 2$ factorial arrangement (eight native grasses: Andropogon lateralis, Aristida laevis, Axonopus affinis, Erianthus angustifolius, Paspalum notatum, Paspalum plicatulum, Piptochaetium montevidense and Sorghastrum pellitum; with and without the application of $100 \mathrm{~kg} \mathrm{ha}^{-1}$ of N).

The species studied were collected from a natural pasture, in the form of cores (six from each species) and they were propagated in the experimental area $\left(96 \mathrm{~m}^{2}\right)$. The distribution of cores, within each block, was done randomly in May 2008. The species evaluated in this experiment were classified into four (A, B, C and D) functional types by Quadros et al. (2008; 2009). Natural grasses were clustered according to their leaf dry matter content $(\mathrm{g} / \mathrm{kg})$ and specific leaf area $\left(\mathrm{m}^{2} / \mathrm{kg}\right)$ : the authors included grasses in the groups cited above in a increasing rank of dry matter content (from $150 \mathrm{~g} / \mathrm{kg}$ for functional type A to more than $500 \mathrm{~g} / \mathrm{kg}$ for functional type D) and in a decreasing order of specific leaf area (from $25 \mathrm{~m}^{2} / \mathrm{kg}$ for functional type A to less than $6 \mathrm{~m}^{2} / \mathrm{kg}$ for functional type D).

Data collection began on January 6th, 2009, when all the grasses were cut. The thermal sum required for the emergence of 2.2 leaves in P. notatum (Eggers et al., 2004) which is equivalent to 350 degree days was used as a criterion for the interval between cuts for prostrate growth habit species (A. affinis, $P$. notatum). For caespitose plants (A. lateralis, A. laevis, E. angustifolius, P. plicatulum, $P$. montevidense and $S$. pellitum) it was considered twice this value, i.e., the thermal sum equivalent to 700 degree days. The prostrate growth habit species were cut five $\mathrm{cm}$ above the soil and the caespitose plants had half of their leaves cut (Mazzanti et al., 1994).

Table 1 - Average monthly temperature and rainfall during the experimental period

\begin{tabular}{lcccc}
\hline \multirow{2}{*}{ Month } & \multicolumn{2}{c}{ Temperature ${ }^{\circ} \mathrm{C}$} & \multicolumn{2}{c}{ Rainfall $(\mathrm{mm})$} \\
\cline { 2 - 5 } & Expected & Real & Expected & Real \\
\hline January & 23.1 & 24.5 & 145.1 & 162.1 \\
February & 24.0 & 23.8 & 130.2 & 166.4 \\
March & 22.2 & 22.9 & 151.7 & 131.7 \\
\hline
\end{tabular}

The amount of urea ( $44 \%$ of $\mathrm{N}$ ) corresponding to $100 \mathrm{~kg} \mathrm{ha}^{-1}$ of $\mathrm{N}$ was diluted in $110 \mathrm{~mL}$ of water and applied on January 5th, 2009 in the area occupied by each species. The thermal sum (TS) was calculated by the equation $\mathrm{TS}=\Sigma \mathrm{ADT}$, in which $\Sigma$ ADT is the sum of average daily temperature for the period (Inmet, 2004). Due to the number of species evaluated (eight), it was decided not to use its growth base temperature in thermal sum calculations. Canopy height $(\mathrm{cm})$, considered as the distance from the ground to the height of folding leaves $(\mathrm{cm})$, was measured using a graduated ruler at one point per plot at the time of data collection of morphogenesis. To evaluate the morphogenetic variables, the technique of "marked tillers" was used (Carrère et al., 1997). In each plot ( $\left.1 \mathrm{~m}^{2}\right), 10$ tillers were marked with colored soft plastic rings, totaling 30 tillers per species in each treatment. The first leaf of each tiller was marked with a water-based ink to serve as a reference for the following evaluations. The measurements were made at intervals of seven days. In each evaluation, the number of green leaves was counted and the length of the blade leaf in expansion was measured in centimeters. Fully expanded leaves were measured from their ligule, while the expanding leaves were measured from the ligule of last expanded leaf. Only the green portion of the leaf blade was measured in senescent leaves. The height of the pseudo stems $(\mathrm{cm})$ was measured with a graduated ruler, at the same occasion that measures of morphogenesis were obtained. The length was measured from the soil until the ligule of the last expanded leaf, except for P. montevidense. From the measurements taken from the marked tillers, the following variables were calculated: leaf appearance rate (leaves/degree days), phyllochron (degree days; days), leaf elongation rate (cm/degree days); leaf senescence rate $(\mathrm{cm} /$ degree days), duration of leaf elongation (degree days), leaf lifespan, (degree days; days), number of green leaves and final length of leaf blades.

Leaf appearance rate was calculated from the slope of the linear regression between the number of leaves per tiller and the accumulated thermal sum. Phyllochron was considered as the inverse value of the slope of this linear regression. The leaf elongation rate was calculated from the ratio between the variation of the length of leaves in elongation between two successive evaluations and the thermal sum accumulated in the corresponding period. Leaf senescence rate was calculated from the ratio between the variation in the length of senescent leaf material between two successive evaluations and the thermal sum accumulated in the corresponding period.

The number of fully expanded leaves and leaves in expansion was counted at each evaluation of the marked 
tillers. The duration of leaf elongation was obtained through the product of phyllochron and the average number of leaves in expansion per tiller.

Collected data were tested by the Shapiro-Wilk normality test. Variables rates of elongation and leaf senescence were transformed using the square root. ANOVA and $\mathrm{F}$ test were conducted, using the GLM (General Linear Model) procedure of SAS statistical program, version 8.2 (2001). In the cases in which difference between the means of species factor was detected, the Tukey test $(\mathrm{P}=5 \%)$ was applied. Correlation test was performed at 5\% level of significance and then, the variables were submitted to regression analysis.

The following mathematical model was used to analyze the variables studied:

$$
\mathrm{Y}_{\mathrm{ikj}}=\mu+\mathrm{B}_{\mathrm{j}+} \mathrm{E}_{\mathrm{i}}+\mathrm{N}_{\mathrm{k}}+\mathrm{EN}_{\mathrm{ik}}+\varepsilon_{\mathrm{ijk}}
$$

In which: $\mathrm{Y}_{\mathrm{ikj}}=$ dependent variables; $\mu=$ mean of all observations; $B_{j}=$ block effect; $E_{i}=$ effect of the $i$-th species; $\mathrm{N}_{\mathrm{k}}=$ effect of the $\mathrm{k}$-th nitrogen; $(\alpha \gamma)_{\mathrm{ik}}=$ effect of the E-th species $\times \mathrm{N}$-th nitrogen interaction; $\varepsilon_{\mathrm{ijk}}=$ experimental error.

\section{Results and Discussion}

The average records for temperature and rainfall were 2.7 and $7.8 \%$ higher than the average values forecast for the months evaluated (Table 1), respectively. These values indicate that during the evaluation period, climatic variables were close to data considered normal. The thermal sum of 350 and 700 degree days was equivalent to average intervals of 14 and 25 days between cuts.

Grasses evaluated were classified into functional types according Quadros et al. $(2008 ; 2009)$ as follows: A. affinis (functional type A); A. lateralis, P. notatum (functional type B); P. plicatulum, P. montevidense (functional type C); A. laevis, E. angustifolius, S. pellitum (functional type D). The leaf lifespan can also be used as a criterion for grouping the species into different functional types, because it is directly linked to the growth and development of plants (Weither et al., 1999).

There was interaction between species and $\mathrm{N}$ for leaf elongation rate ( $\mathrm{P}=0.0214$; Table 2). Paspalum plicatulum showed the highest values for leaf elongation rate when $100 \mathrm{~kg} \mathrm{ha}^{-1}$ of $\mathrm{N}$ were applied, with no difference from Aristida laevis, Erianthus angustifolius and Sorghastrum pellitum. The effect of $\mathrm{N}$ on leaf elongation rate could be attributed to $\mathrm{N}$ accumulation along with the cell division zone (Gastal \& Nelson, 1994). According to Lemaire \& Gastal (2002), when this nutrient is applied at the vegetative stage of plants, it strongly increases leaf elongation rate.
The species that responded positively to $\mathrm{N}$ application, such as A.laevis, E.angustifolius, P.plicatulum and S.pellitum, are classified as belonging to the functional types $\mathrm{C}$ and D (Quadros et al., 2008; 2009). These are species adapted to marginal environments, which are less fertile, with soil and climatic limitations, which contributed to the development of the characteristic of conservation of resources captured, with low internal recycling of nutrients (Quadros et al., 2009).

Piptochaetium montevidense, also classified in the category of resource conservation species, did not respond to $\mathrm{N}$ application, which might be related to the fact that it is a cool season species, with higher leaf elongation rate in periods of the year with milder temperatures. High temperatures were considered as a limiting factor for the growth of Brisa subaristata, a cool season species that like $P$. montevidense has its yield and frequency reduced on natural pastures during the warm season (Denardin, 2001).

Andropogon lateralis, Paspalum notatum and Axonopus affinis, considered as resource acquisition species (Quadros et al., 2009), had a similar behavior and did not respond to the $\mathrm{N}$ applied. The absence of nitrogen response could have been interfered by factors such as low uptake of $\mathrm{N}$ by the plants, the nitrogen source used, lack of fractioning, amount applied and the natural fertility of the soil (Pizzaro, 2003). The ability of internal remobilization of nitrogen necessary for the recovery of plants after defoliation is also attributed to these species.

A. lateralis is one of the live components with highest expression in the Pampa biome (Damé et al., 1997), and it did not change leaf elongation rate under $\mathrm{N}$ application (Table 2) and this response assumes great importance in pasture management in this biome. For this species, however, when $400 \mathrm{~kg} \mathrm{ha}^{-1}$ of $\mathrm{N}$ were applied, there was a crescent response in leaf elongation rate until the level of $200 \mathrm{~kg} \mathrm{ha}^{-1} \mathrm{~N}$ (Bandinelli et al., 2003). For the $100 \mathrm{~kg} \mathrm{ha}^{-1}$ of $\mathrm{N}$ applied in the summer, those authors observed leaf elongation rate $69 \%$ higher than the observed in this study (Table 2). Trindade \& Rocha (2001) attributed the higher leaf elongation rate of $A$. lateralis to the increased availability of nutrients that, in their research context, was promoted by grassland burning.

Andropogon lateralis stands out for its phenotypic plasticity, and this process involves physiological changes in plants when they are exposed to intense events such as fire and grazing (Trindade \& Rocha, 2001; 2002). This species, depending on the extent to which events occur, can present tufted or more decumbent growth habit, which will probably change its response to $\mathrm{N}$ fertilization.

Eggers (1999) observed values of leaf elongation rate $52 \%$ higher in $P$. notatum, in a similar average temperature 
during the experimental period $\left(21.3^{\circ} \mathrm{C}\right)$. This species showed seasonal effect on leaf elongation rate related to temperature. The leaf elongation rate of $P$. notatum ecotype "André da Rocha" was increased because of the supply of $\mathrm{N}\left(\mathrm{NH}_{4} \mathrm{NO}_{3}\right)$ with mean values of 1.4, 1.7, 2.6 and 3.2 (cm/degree days), respectively, for concentrations of 38 , 75,150 and $300 \mathrm{mg} \mathrm{dm}^{-3} \mathrm{~N}$ per pot (Nabinger et al., 2003).

There was no interaction between species and $\mathrm{N}$ fertilization for leaf appearance rate $(P=0.6295)$; there was no difference for nitrogen fertilization $(\mathrm{P}=0.9549)$, and there was difference between the evaluated species $(\mathrm{P}<0.0001$; Table 3).

The leaf appearance rate is responsible for the photosynthetic tissue formation pace, which accounts for the tillering potential and, along with leaf elongation rate, determines the intensity of plant growth (Confortin et al., 2010). A. affinis showed the highest values for leaf appearance rate, which was not statistically different from P. notatum (Table 3). The increase in the leaf appearance rate could reduce the probability of defoliation and it can be considered a mechanism of avoidance to grazing because a high number of small leaves and buds reduce the chance of removing leaf tissue and increase the chance of regrowth by basal tillering (Briske, 1991). The dominance of prostrate species such as $P$. notatum and $A$. affinis occurs when pasture is managed with low forage allowances, which shows the adaptation of these species at high intensities of grazing (Maraschin, 2009).

Andropogon lateralis and Paspalum plicatulum showed intermediate values for leaf appearance rate when compared with other species evaluated. Bandinelli et al. (2003) observed the highest values for leaf appearance rate at levels of 100 and $200 \mathrm{~kg} \mathrm{ha}^{-1}$ of $\mathrm{N}$ fertilization for the first species, regardless of season. However, according to Gastal \& Lemaire (1988) leaf appearance rate is little influenced by nitrogen deficiency in cool season grasses.

The leaf appearance and elongation rates show opposite behaviors (Zarrough et al., 1984), which was observed in $A$. laevis, E. angustifolius and S. pellitum. They presented the lowest appearance rate and the highest elongation rate. The same was not observed for $P$. montevidense, which showed low elongation and leaf appearance rate, which may be related to the fact that it is a cool season species. The thermal effect is similar for leaf appearance rate and elongation, and these variables respond favorably when the temperature is close to the ideal range for the species (Townsend, 2008).

There was no interaction between species and nitrogen fertilization for phyllochron $(\mathrm{P}=0.9572)$ and no difference in concentrations of $\mathrm{N}$ fertilization $(\mathrm{P}=0.6703)$, but there were differences between the species tested $(\mathrm{P}<0.0001$; Table 3$)$.

Table 2 - Leaf elongation rate of native forage species with and without nitrogen fertilization (100 kg/ha)

\begin{tabular}{lrr}
\hline Species & \multicolumn{2}{c}{ Leaf elongation rate (cm/degrees-day) } \\
\cline { 2 - 4 } & \multicolumn{1}{c}{ Without nitrogen } & With nitrogen \\
Andropogon lateralis & $0.0215 \mathrm{~cd} \pm 0.0049$ & $0.0198 \mathrm{~cd} \pm 0.0060$ \\
Aristida laevis & $0.0336 \mathrm{abcd} \pm 0.0047$ & $0.0374 \mathrm{abc} \pm 0.0033$ \\
Axonopus affinis & $0.0100 \mathrm{~d} \pm 0.0025$ & $0.0542 \mathrm{ab} \pm 0.0042$ \\
Erianthus angustifolius & $0.0322 \mathrm{abcd} \pm 0.0213$ & $0.0154 \mathrm{~cd} \pm 0.0006$ \\
Paspalum notatum & $0.0158 \mathrm{~cd} \pm 0.0012$ & $0.0558 \mathrm{a} \pm 0.0117$ \\
Paspalum plicatulum & $0.0382 \mathrm{abc} \pm 0.0051$ & $0.0130 \mathrm{~d} \pm 0.0027$ \\
Piptochaetium montevidense & $0.0170 \mathrm{~cd} \pm 0.0034$ & $0.0484 \mathrm{ab} \pm 0.0064$ \\
Sorghastrum pellitum & $0.0310 \mathrm{bcd} \pm 0.0127$ & 51.0 \\
Coefficient of variation $(\%)$ & &
\end{tabular}

Means followed by different letters in the same column are different by Tukey's test $(\mathrm{P}<0.05)$.

Table 3 - Leaf appearance rate, phyllochron and leaf lifespan of native forage grasses

\begin{tabular}{lccc}
\hline Species & $\begin{array}{c}\text { Leaf appearance rate } \\
\text { (leaves/degrees-day) }\end{array}$ & $\begin{array}{c}\text { Phyllochron } \\
\text { (degrees-day) }\end{array}$ & $\begin{array}{c}\text { Leaf lifespan } \\
\text { (degrees-day) }\end{array}$ \\
\hline Andropogon lateralis & $0.0060 \mathrm{bc} \pm 0.0012$ & $166.7 \mathrm{c} \pm 28.68$ & $563.1 \mathrm{c} \pm 63.98$ \\
Aristida laevis & $0.0030 \mathrm{~d} \pm 0.0003$ & $333.3 \mathrm{~b} \pm 32.77$ & $1071.8 \mathrm{a} \pm 147.45$ \\
Axonopus affinis & $0.0075 \mathrm{a} \pm 0.0011$ & $506.2 \mathrm{c} \pm 97.14$ & $1039.0 \mathrm{a} \pm 200.19$ \\
Erianthus angustifolius & $0.0031 \mathrm{~d} \pm 0.0004$ & $322.6 \mathrm{~b} \pm 50.03$ & $704.5 \mathrm{bc} \pm 66.27$ \\
Paspalum notatum & $0.0074 \mathrm{ab} \pm 0.0011$ & $135.1 \mathrm{c} \pm 22.37$ & $518.4 \mathrm{c} \pm 52.24$ \\
Paspalum plicatulum & $0.0058 \mathrm{c} \pm 0.0003$ & $172.4 \mathrm{c} \pm 9.52$ & $836.3 \mathrm{ab} \pm 136.73$ \\
Piptochaetium montevidense & $0.0023 \mathrm{~d} \pm 0.0004$ & $434.8 \mathrm{a} \pm 68.95$ & $991.9 \mathrm{a} \pm 127.35$ \\
Sorghastrum pellitum & $0.0029 \mathrm{~d} \pm 0.0005$ & $344.8 \mathrm{~b} \pm 57.27$ & 16.4 \\
Coefficient of variation (\%) & 15.89 & 17.07 & \\
\hline
\end{tabular}

Means followed by different letters in the same column are different by Tukey's test $(\mathrm{P}<0.05)$. 
The interval for the appearance of new leaves is related to thermal sum (Moore \& Moser, 1995) and it is a speciesspecific characteristic. The highest phyllochron was observed for P. montevidense and the lowest for A. lateralis, A. affinis, $P$. notatum and $P$. plicatulum. The values were intermediate for A. laevis, E. angustifolius and S. pellitum.

The higher phyllochron observed for $P$. montevidense (Table 3) was probably due to its classification as a winterearly spring species. In a study with the same species, Denardin (2001) observed no effect from $\mathrm{N}$ fertilization on the phyllochron value which was $18 \%$ higher than the observed in this experiment. For A. lateralis, Bandinelli et al. (2003) observed values for phyllochron 23\% higher than those observed in this study (Table 3). This range of variability could be expected in native grasses which represent a natural population rather than selected breeds.

Phyllochron was independent of the grazing intensity in $P$. notatum, with a mean value of 164 degree days in the summer (Eggers et al., 2004), 18\% higher than the observed value (Table 3). Townsend (2008), analyzing ecotypes of $P$. notatum "André da Rocha" and "Bagual", observed average values of phyllochron of 111 and 115 degree days, respectively. These values were on average $20 \%$ lower than those observed for P. notatum (Table 3). For Cynodon dactylon var. Coastcross, Vilela et al. (2005) observed that the average time for new leaf appearance was 3.7 days in the summer. Even native species with lower phyllochron, averaging 6.7 days, A. lateralis (166.7 degree days), $A$. affinis (133.3 degree days), $P$. notatum (135.1 degree days) and $P$. plicatulum (172.4 degree days) required more days for appearance of a new leaf, when compared with Coastcross. Evaluating Pennisetum americannum, Gonçalves \& Quadros (2003) observed interval of 7.3 days (81.5 degree days) between the appearances of successive leaves. Among the species evaluated, A. lateralis (166.7 degree days) and $P$. plicatulum (172.4 degree days) presented the interval between successive leaf appearances similar to those observed by the authors, with an average of 7.5 days.

There was no species $\times \mathrm{N}$ interaction for leaf lifespan $(\mathrm{P}=0.9709)$ or effect from nitrogen fertilization $(\mathrm{P}=$ $0.6287)$, but there were differences between the species $(\mathrm{P}<0.0001$; Table 3$)$.

The highest values for leaf lifespan were observed in A. laevis, E. angustifolius and S. pellitum, and the lowest values in A. lateralis, A. affinis and $P$. plicatulum. Intermediate values were observed in $P$. notatum, which did not differ from species that had the lowest leaf lifespan, and $P$. montevidense did not differ from species with higher values.
The species A. laevis, E. angustifolius and S. pellitum with cespitose growth habit form dense clumps with greater leaf longevity. Besides that, they are species of lower internal recycling of nutrients and denser leaf structures (Quadros et al., 2009). These species would be able to accumulate more herbage mass and achieve high ceiling yield (maximum amount of green material per area) according to Nabinger \& Pontes (2001). A lateralis, A. affinis and $P$. plicatulum showed the lowest values for leaf lifespan, suggesting a high renewal of canopy leaves and therefore would be adapted to more frequent defoliation. The observed leaf lifespan of $P$. notatum (Table 3 ) was $3 \%$ higher than the ecotype "André da Rocha" and 4\% lower than "Bagual" when $180 \mathrm{~kg} / \mathrm{ha}$ of nitrogen were applied in the summer (Townsend, 2008). For the ecotype "André da Rocha", which received 38 and $75 \mathrm{mg} /$ pot of $\mathrm{N}$, the leaf lifespan was estimated as 538 and 674 degree days, respectively (Nabinger et al., 2003). The results observed for $P$. notatum were 45 degree days lower than the values obtained by Eggers (1999). For P. montevidense, in December, Denardin (2001) observed leaf lifespan of approximately 39 days, similar to the 36.7 days observed in this experiment.

The species evaluated in this experiment were classified into four (A, B, C and D) functional types by Quadros et al. (2008; 2009), according to the dry matter content $\left(\mathrm{g} \mathrm{kg}^{-1}\right)$ and specific leaf area $\left(\mathrm{m}^{2} / \mathrm{kg}\right): A$. affinis (functional type A); $A$. lateralis and $P$. notatum (functional type B); P. plicatulum and $P$. montevidense (functional type C); and A. laevis, E. angustifolius and $S$. pellitum (functional type D). The leaf lifespan can also be used as a criterion for grouping the species into different functional types, because it is directly linked to the growth and development of plants (Weither et al., 1999). A. affinis showed high leaf appearance rate and, consequently, low phyllochron and low leaf lifespan. There was no difference between the average phyllochron and the leaf lifespan of this species and $A$. lateralis and $P$. notatum. As for the socalled D species, A. laevis, E. angustifolius and S. pellitum, it presents similar phyllochron and leaf lifespan, which confirms its inclusion in the same functional type according to the classification made by Quadros et al. (2008; 2009).

Piptochaetium montevidense and Paspalum plicatulum are classified as belonging to functional type $\mathrm{C}$ according to Quadros et al. (2008), and they presenting different phyllochron and leaf lifespan. P. plicatulum is characterized by being a species that alters its morphogenetic program in response to environmental variations (Quadros et al., 2009), in addition to present different ecotypes (Nabinger $\&$ Dall'Agnol, 2008). Thus, this species can fit into different functional types (Quadros et al., 2009). 
In native pasture managed with rotational stocking method, phyllochron and leaf lifespan are morphogenetic characteristics associated and they are important clues to determine efficient management practices, because they can define more or less frequent defoliation regimes (Nabinger, 1996).

In species with prostrate growth habit, the interval between cuts could be determined by the thermal sum required for the appearance of 2.2 expanding leaves (Eggers et al., 2004). For A. affinis and P. notatum, the observed results show that 294 degree days are required for the appearance of the same number of leaves. This lower value may indicate that it is possible to use these species more frequently in order to optimize the use of pasture and reduce losses due to senescence.

In species with caespitosae growth habit, according to the value of phyllochron (Table 3), three groups were formed, with mean values of 166.7, 333.6 and 434.8 degree days. The range of 700 degree days would be appropriate for the species A. laevis, E. angustifolius and S. pellitum for the appearance of 2.2 leaves. A. lateralis was managed as a species of caespitosae growth habit by cutting management and thermal sum. However, this species had average canopy height of $17 \mathrm{~cm}$, differing from prostrate and caespitose species $(\mathrm{P}<0.0001)$, which showed mean values 8.3 and $31.0(\mathrm{~cm})$, respectively. The height of A. lateralis is associated with the management intensity applied and it can reach $120 \mathrm{~cm}$ or more (Nabinger \& Dall'Agnol, 2008). From the results observed for this species, only 367 degree days are necessary for the appearance of 2.2 leaves. The data collected from $P$. montevidense would not be relevant as management indicators, due to its small contribution to the herbage mass in the summer.

There was no interaction between species and nitrogen on the number of green leaves $(\mathrm{P}=0.5978)$ and no difference for nitrogen fertilization ( $\mathrm{P}=0.1641)$, but there was difference between the species ( $\mathrm{P}<0.0001$; Table 4).
The number of green leaves is a very stable genotype characteristic in the absence of water or nutritional deficiencies and it can vary widely according to species (Nabinger \& Pontes, 2001). The highest value for the number of green leaves was observed in $P$. notatum, and the lowest in P. montevidense. The other species (Table 4) showed intermediate values.

In P. notatum, Eggers (1999) observed an average of four green leaves. In A. lateralis, Cruz \& Boldrini (1998) observed about three leaves and in P. montevidense 1.4 green leaves (Denardin, 2001). The results observed (Table 4) were close to those observed in the literature, because it is a stable genetic characteristic (Nabinger, 1996).

There was no interaction between species and nitrogen for length of the leaf blade ( $\mathrm{P}=0.0911$ ), or difference in levels of nitrogen fertilization ( $\mathrm{P}=0.9131)$, but there was difference between the species tested $(\mathrm{P}<0.0001$; Table 4$)$.

The highest values for leaf blade length were observed in A. laevis and E. angustifolius, and the lowest in A. lateralis, A. affinis, $P$. notatum and $P$. montevidense. For $P$. plicatulum and $S$. pellitum, intermediate values were observed. The length of the leaves was adjusted to a linear regression model according to the height of pseudo stems $\left(\mathrm{y}=4.58+1.00 \mathrm{x} ; \mathrm{R}^{2}=0.54 ; \mathrm{P}<0.0001\right)$. Thus, for each centimeter of the height of pseudo stems, there was an increase of one centimeter in length of leaf blades. This result confirms that leaf blade length is positively associated with the height of pseudo stems, which defines the extension of the growth area to be covered by the blade in expansion, so it influences the final size of the leaf blade (Chapman \&Lemaire, 1993; Nabinger\& Pontes, 2001).

There was no interaction between species and $\mathrm{N}$ for the duration of leaf elongation $(\mathrm{P}=0.7799)$ as well as for $\mathrm{N}$ fertilization $(\mathrm{P}=0.6826)$; however, there was difference between the species $(\mathrm{P}<0.0001$; Table 5).

The duration of leaf elongation was higher in A. laevis and E. angustifolius and lower in A. lateralis, A. affinis and

Table 4 - Number of green leaves, length of leaf blade and pseudo stem height of native forage grasses

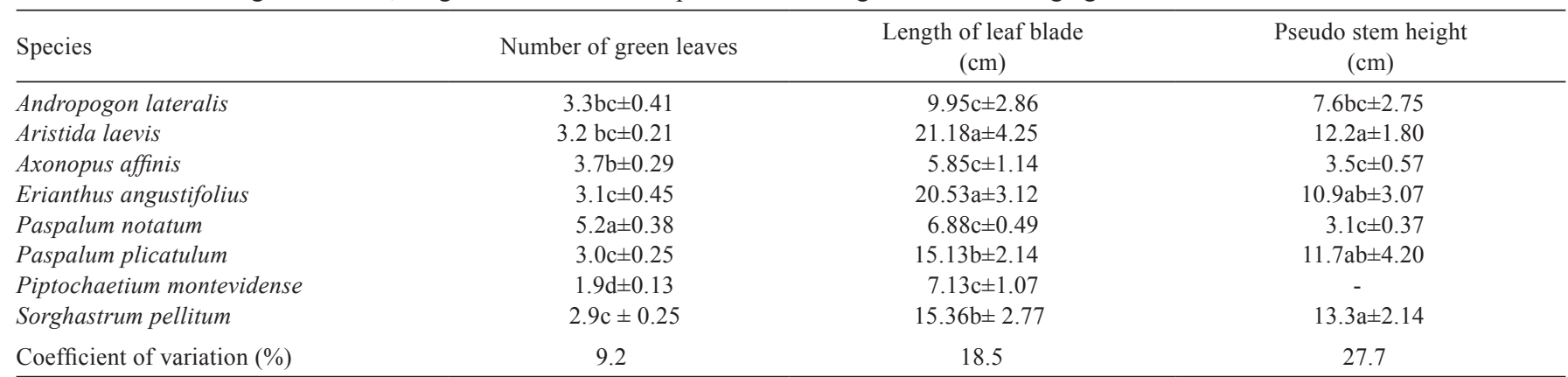

Means followed by different letters in the same column are different by Tukey's test $(\mathrm{P}<0.05)$. 
Table 5 - Duration of leaf elongation and leaf senescence rate of native forage grasses

\begin{tabular}{lcc}
\hline Species & $\begin{array}{c}\text { Duration of leaf elongation } \\
\text { (degrees-day) }\end{array}$ & $\begin{array}{c}\text { Leaf senescence rate } \\
\text { (cm/degrees-day) }\end{array}$ \\
\hline Andropogon lateralis & $284.0 \mathrm{~d} \pm 45.04$ & $0.0251 \mathrm{ab} \pm 0.0114$ \\
Aristida laevis & $711.3 \mathrm{a} \pm 81.56$ & $0.0478 \mathrm{a} \pm 0.0184$ \\
Axonopus affinis & $258.3 \mathrm{~d} \pm 49.92$ & $0.0181 \mathrm{ab} \pm 0.0057$ \\
Erianthus angustifolius & $638.2 \mathrm{a} \pm 73.81$ & $0.0413 \mathrm{ab} \pm 0.0221$ \\
Paspalum notatum & $379.1 \mathrm{~cd} \pm 61.27$ & $0.0141 \mathrm{~b} \pm 0.0034$ \\
Paspalum plicatulum & $309.0 \mathrm{~d} \pm 21.91$ & $0.0356 \mathrm{ab} \pm 0.0163$ \\
Piptochaetium montevidense & $485.7 \mathrm{bc} \pm 76.21$ & $0.0145 \mathrm{~b} \pm 0.0045$ \\
Sorghastrum pellitum & $511.7 \mathrm{~b} \pm 86.19$ & $0.0396 \mathrm{ab} \pm 0.0311$ \\
Coefficient of variation (\%) & 14.6 & 1.1 \\
\hline
\end{tabular}

Means followed by different letters in the same column are different by Tukey's test $(\mathrm{P}<0.05)$.

$P$. plicatulum. Intermediate values were observed in $P$. notatum, $P$. montevidense, and $S$. pellitum. P. notatum did not differ from species that had the lowest duration of leaf elongation.

There is a positive relationship between the duration of leaf elongation and canopy height $(\mathrm{r}=0.55 ; \mathrm{P}<0.0001)$ and a negative relationship between duration of leaf elongation and leaf appearance rate $(\mathrm{r}=-0.78 ; \mathrm{P}<0.0001)$. In Dactylis glomerata, it was observed that the increase in the duration of leaf elongation in function of canopy height was due to the greater length of pseudo stems (Duru \& Ducrocq, 2000).

There was no species $\times \mathrm{N}$ interaction for leaf senescence rate $(\mathrm{P}=0.2789)$ and no difference in concentrations of $\mathrm{N}$ fertilization ( $\mathrm{P}=0.9045)$, but there was difference between the evaluated species ( $\mathrm{P}=0.0057$; Table 5).

The highest leaf senescence rate was observed in $A$. laevis, and the lowest in P. notatum and P. montevidense, while the other species showed intermediate rates of senescence. Leaf senescence is a way for a plant to recycle some of the valuable and often scarce mineral nutrients, such as nitrogen and phosphor. In A. lateralis, the value observed was $20 \%$ higher than those observed by Bandinelli et al. (2003), who also found no influence of nitrogen fertilization on this variable in the summer season. In $P$. notatum, Eggers (1999) observed leaf senescence rate $31 \%$ higher for the same species in this experiment, but these differences could be water stressrelated.

\section{Conclusions}

An increase in frequency of utilization, based on leaf elongation duration, with an interval of around 300 degree days, could enhance herbage harvest efficiency for A. lateralis, A. affinis, P. notatum and P. plicatulum. A 700 degree day thermal time interval between defoliations would be appropriate for the A. laevis, E. angustifolius and $S$. pellitum species. Leaf elongation rate is affected by $\mathrm{N}$ application in Aristida laevis, Erianthus angustifolius Paspalum plicatulum and Sorghastrum pellitum, the resource conservative species. The other morphogenetic and structural characteristics of these species are not modified by nitrogen fertilization.

\section{References}

ANUALPEC. Anuário da pecuária brasileira. São Paulo: Prol Editora Gráfica, 2007. 368p.

BANDINELLI, D.G.; QUADROS, F.L.F.; GONÇALVES, E.N. et al. Variáveis morfogênicas de Andropogon lateralis Nees submetido a níveis de nitrogênio nas quatro estações do ano. Ciência Rural, v.33, n.1, p.71-76, 2003.

BOLDRINI, I.I. Campos do Rio Grande do Sul: Caracterização fisionômica e problemática ocupacional. Boletim do Instituto de Biociências, n.56, p.1-39, 1997.

BRISKE, D.D. Developmental morphology and physiology of grasses. In: HEITSCHMIDT, R.K.; STUTH, J.W. (Eds.) Grazing management. Portland: Timber, 1991. p.85-108.

CARRÈRE, P.; LOUAULT, F.; SOUSSANA, J.F. Tissue turnover within grass-clover mixed swards grazed by sheep. Methodology for calculating growth senescence and intake fluxes. Journal of Applied Ecology, v.34, p.333-348, 1997.

CHAPMAN, D.F.; LEMAIRE, G. Morphogenetic and structural determinants of plant regrowth after defoliation. In: INTERNATIONAL GRASSLAND CONGRESS, 17., 1993. Proceedings... [S.I.]: New Zealand Grassland Association; KEELING \& MUNDI, 1993. p.95-104.

CONFORTIN, A.C.C.; QUADROS, F.L.F.; ROCHA, M.G. Morfogênese e estrutura de azevém anual submetido a três intensidades de pastejo. Acta Scientarum. Animal Sciences, v.32, n.4, p.385-391, 2010.

CRUZ, F.P.; BOLDRINI, I.I. Dinâmica de crescimento, desenvolvimento e desfolhação em Andropogon lateralis Nees. In: REUNIÃO DO GRUPO TÉCNICO EM FORRAGEIRAS DO CONE-SUL - ZONA CAMPOS, 17., 1998, Lages. Anais... Lages: Epagri/UDESC, 1998. p.99.

CRUZ, P.; QUADROS, F.L.F.; THEAU, J.P. et al. Leaf traits as functional descriptors of the intensity of continuous grazing in native grasslands in the South of Brazil. Rangeland Ecology \& Management, v.63, p.350-358, 2010.

DAMÉ, P.R.V.; QUADROS, F.L.F.; KERSTING, C.E.B. et al. Efeitos de queima seguido de pastejo ou diferimento sobre a produção, qualidade, cobertura do solo e sistema radicular de uma pastagem natural. Ciência Rural, v.27, n.1, p.133-137, 1997. 
DENARDIN, R.B.N. Avaliações morfogênicas e agronômicas de Piptochaetium montevidense (Spreng.) Parodi e Briza subaristata Lam. 2001. 218f. Tese (Doutorado em Zootecnia) Curso de Pós-graduação em Zootecnia, Universidade Federal do Rio Grande do Sul, Porto Alegre.

DURU, M.; DUCROCQ, H. Growth and senescence of the successive grass leaves on a tiller ontogenic development and effect of temperature. Annals of Botany, v.85, p.635-643, 2000.

EGGERS, L. Morfogênese e desfolhação de Paspalum notatum Fl. e Coelorhachis selloana (Hack.) Camus em níveis de oferta de forragem. 1999. 148f. Tese (Doutorado em Zootecnia) - Curso de Pós-graduação em Zootecnia, Universidade Federal do Rio Grande do Sul, Porto Alegre.

EGGERS, L.; CADENAZZI, M.; BOLDRINI, I.I. Phyllochron of Paspalum notatum Fl. and Coelorhachis selloana (Hack.) Camus in natural pasture. Scientia Agrícola, v.61, n.4, p.353-357, 2004.

EMPRESA BRASILEIRA DE PESQUISA E AGROPECUÁRIA - EMBRAPA. Centro Nacional de Pesquisa de Solos. Sistema brasileiro de classificação de solos. Brasília: Embrapa; Rio de Janeiro, 2006. 306p.

GASTAL, F.; LEMAIRE, G. Study of a tall fescue sward under nitrogen deficiency conditions. In: GENERAL MEETING OF EUROPEAN GRASSLAND FEDERATION, 12., 1988, Dublin. Proceedings... Dublin: Irish Grassland Association, 1988. p.323-327.

GASTAL, F.; LEMAIRE, G. N uptake and distribution in crops: an agronomical and ecophysiological perspective. Journal of Experimental Botany, v.53, n.370, p.789-799, 2002.

GASTAL, F.; NELSON, C.J. Nitrogen use whitin the growing leaf blade of tall fescue. Plant Physiology, v.105, p.191-197, 1994.

GONÇALVES, E.N.; QUADROS, F.L.F. Morfogênese de milheto (Pennisetum americanum (L.) Leeke) em pastejo com terneiras, recebendo ou não suplementação. Ciência Rural, v.33, n.6, p.1123-1128, 2003.

INSTITUTO NACIONAL DE METEREOLOGIA - INM. Divisão de Observação Metereológica. Curso de atualização para observador meteorológico de superfície. Porto Alegre, 2004. 57p.

LEMAIRE, G.; CHAPMAN, D. Tissue flows in grazed plant communities. In: HODGSON, J.; ILLIUS, A.W. (Eds.) The ecology and management of grazing systems. Wallingford: $C A B$ International, 1996. p.3-36.

MARASCHIN, G.E. Manejo do campo nativo, produtividade animal, dinâmica da vegetação e adubação de pastagens nativas do sul do Brasil. In: . Campos Sulinos: conservação e uso sustentável da biodiversidade. Brasília: Ministério do Meio Ambiente, 2009. p.248-259.

MAZZANTI, A.; LEMAIRE, G. Effect of nitrogen fertilization upon herbage production of tall fescue sward continuously grazed by sheep. 2. Consumption and efficiency of herbage utilization. Grass and Forage Science, v.49, p.352-359, 1994.

MINISTÉRIO DO MEIO AMBIENTE - MMA. Áreas prioritárias para conservação, uso sustentável e repartição de benefícios da Biodiversidade Brasileira. Brasília: MMA/SBF, 2007. $328 \mathrm{p}$.

MOORE, K.J.; MOSER, L.E. Quantifying developmental morphology of perennial grasses. Crop Science, v.35, n.1, p.37-43, 1995.

NABINGER, C. Princípios da exploração intensiva de pastagens. In: PRODUÇÃO DE BOVINOS A PASTO - SIMPÓSIO SOBRE MANEJO DA PASTAGEM, 13., 1996, Piracicaba. Anais... Piracicaba: Fealq, 1996. p.15-96.
NABINGER, C.; PONTES, L.S. Morfogênese de plantas forrageiras e estrutura do pasto. In: REUNIÃO ANUAL DA SOCIEDADE BRASILEIRA DE ZOOTECNIA. A produção animal na visão dos brasileiros, 38., 2001, Piracicaba. Anais... Piracicaba: Fundação de Estudos Agrários Luiz de Queiroz, 2001. p.755-771.

NABINGER, C.; SANTOS, R.J.; CRANCIO, L.A. et al. Resposta de Paspalum notatum var. latiflorum à disponibilidade de $\mathrm{N}$ em morfogênese. In: REUNIÃO ANUAL DA SOCIEDADE BRASILEIRA DE ZOOTECNIA, 40., 2003, Santa Maria. Anais... Santa Maria, 2003. (CD-ROM).

NABINGER, C.; DALL'AGNOL, M. Principais gramíneas nativas do RS: características gerais, distribuição e potencial forrageiro. In: SIMPÓSIO DE FORRAGEIRAS E PRODUÇÃO ANIMAL, 3., 2008, Porto Alegre. Anais... Porto Alegre: UFRGS, 2008. p.7-54.

PIZARRO, E.A. Nociones sobre introducción y evaluación agronómica de plantas forrajeras. [Curitiba]: UFPR. Curso de Pós-Graduação em Agronomia, 2003. Apostia, n.p.

QUADROS, F.L.F.; BANDINELLI, D.G. Efeito da adubação nitrogenada e de sistemas de manejo sobre a morfogênese de Lolium multiflorum Lam. e Paspalum urvillei Steud. em ambiente de várzea. Revista Brasileira de Zootecnia, v.34, n.1, p.44-53, 2005.

QUADROS, F.L.F; GARAGORRY, F.C.; ROSSI, G.E. Consistência dos tipos funcionais formados a partir dos atributos morfológicos: Área foliar específica e teor de matéria seca. In: REUNIÓN DEL GRUPO TÉCNICO EM FORRAJERAS DEL CONO SUR GRUPO CAMPOS, 22., 2008, Minas. Anais... Minas: INIA, 2008, p.27-40.

QUADROS, F.L.F; TRINDADE, J.P.P; BORBA, M. A abordagem funcional da ecologia campestre como instrumento de pesquisa e apropriação do conhecimento pelos produtores rurais. In: Campos Sulinos: conservação e uso sustentável da biodiversidade. Brasília: Ministério do Meio Ambiente, 2009. p.206-213.

SANTOS, R.J.; NABINGER, C.; THUROW, J.W. et al. Características morfogênicas e estruturais de quatro gramíneas nativas do RS. In: REUNIÃO ANUAL DA SOCIEDADE BRASILEIRA DE ZOOTECNIA, 41., 2004, Campo Grande. Anais... Campo Grande: SBZ, 2004. (CD-ROM).

TOWNSEND, C.R. Características produtivas de gramíneas nativas do gênero Paspalum, em resposta à disponibilidade de nitrogênio. 2008. 267f. Tese (Doutorado em Zootecnia) - Curso de Pós-graduação em Zootecnia, Universidade Federal do Rio Grande do Sul, Porto Alegre.

TRINDADE, J.P.P.; ROCHA, M.G. Rebrotamento de capim caninha (Andropogon lateralis Nees) sob efeito do fogo. Ciência Rural, v.31, n.6, p.1057-1061, 2001.

TRINDADE, J.P.P.; ROCHA, M.G. Rebrotamento de capim caninha (Andropogon lateralis Nees) sob efeito de fogo e pastejo. Ciência Rural, v.32, n.1, p.141-146, 2002.

VILELA, D.; PAIVA, P.C.A.; LIMA, J.A. et al. Morfogênese e acúmulo de forragem em pastagem de Cynodon dactylon cv. coastcross em diferentes estações de crescimento. Revista Brasileira de Zootecnia, v.34, n.6, p.1891-1896, 2005.

WEITHER, E.; VAN DER WERF, A; THOMPSON, K. et al. Challenging Theophrastus: a common core list of plants traits for functional ecology. Journal Vegetational Science, v.10, p. 609-620, 1999.

ZARROUGH, K.M.; WILSON, C.J.; SLEPER, D.A. Inter-relationship between rates of leaf appearance and tillering in selected tall fescue populations. Crop Science, v.24, n.4, p.565-568, 1984. 